\title{
Trace Metal Concentration in the Tissue (Muscle) of Moon Fish (Citharinus citharus) from Taylor Creek in Bayelsa State, Nigeria.
}

\author{
${ }^{1}$ Ogaga Augustine Aghoghovwia, ${ }^{2}$ Dagwokapu Peter Ikogha \\ Department of Fisheries/Livestock Production Technology-Niger Delta University, Wilberforce Island-Bayelsa \\ State Nigeria.
}

\begin{abstract}
Levels of three trace metals Copper $(\mathrm{Cu})$, Lead $(\mathrm{Pb})$ and Cadmium $(\mathrm{Cd})$ in moon fish (Citharinus citharus) from Taylor Creek, Bayelsa State were studied to estimate the pollution potential of the creek and risk posed to humans. Fish samples were collected from 3 stations and processed according to (APHA). Trace metals were determined using spectrophotometry 200A. A total of 3 fish samples from each station were collected and sorted into three size group. Values of trace metal concentration differed significantly $(P<0.05)$ between the different sizes of fish at the different stations. The variations of trace metals obtained in various sizes of fish were large $[\mathrm{Cu}(1.98 \pm 0.11 \mu \mathrm{g} / \mathrm{g})$; $\mathrm{Pb}(1.8 .1 \pm 0.60 \mu \mathrm{g} / \mathrm{g})$; $\mathrm{Cd}(1.72 \pm 0.98 \mu \mathrm{g} / \mathrm{g})]$, while for the smallest sizes $\mathrm{Cu}[(1.39 \pm 0.13 \mu \mathrm{g} / \mathrm{gPb}(0.09 \pm 0.1071 \mathrm{~g} / \mathrm{g}) ; \mathrm{Cd}(0.91 \pm 0.21 \mu \mathrm{g} / \mathrm{g})]$. In conclusion, it was observed that the moon fish Citharinus citharus obtained from Taylor Creek were burdened with all metals analyzed in the study. The level of metals detected was all higher than the maximum allowable limit in food fish stipulated by statutory bodies. The Taylor Creek is continuously polluted hence the creek should be monitored periodically to avoid excessive intake of trace metals by the aquatic life and humans that depend on it for fish protein.
\end{abstract}

Keyword:Trace metal, Pollution potential, Taylor creek, Citharinuscitharus, Fish sizes

\section{Introduction:}

Taylor Creek - a fresh water non-tidal creek, flows through a region of Niger Delta which has been urbanized and industrialized due to the quest for crude oil and natural gas, a natural resource that is in abundance in this area.Taylor Creek receives loads of human and industrial effluents which may be detrimental to the quality of water in the creek.Contaminants and pollutants from various source flow through the water body before finally settling at the bottom sediment, which acts as sink for contaminants in aquatic system (Much et al., 2003., Adams et al., 1992., Burton and Scot, 1992).Moon fish belong to the family Citharinidae-one of the world's most widely distributed bony fish (Ikogha 2012). Many plant and animal species have been proposed as bio-indicators for monitoring a variety of contaminants in the aquatic ecosystem (Boiaet al., 2011, AstorgaEspanaet al., 1999).Metals enter the aquatic environment by atmospheric deposition, or through anthropogenic sources, such as industrial and mining wastes (Adametal., 2012).

Taylor creek is an area where much industrial and domestic activities take place with a resultant deposition of numerous industrial and municipal wastes which are detrimental to aquatic/human life (Ikogha, 2012). Fish is considered as one of the main protein sources of food for humans. Water pollution leads to fish contamination with toxic metals from many sources e.g domestic/industrial effluents, natural and run off (Rasheed, 2001). Fish living in polluted water may accumulate toxic trace metals via their food chains. Thus analysis of metallic status in aquatic organisms provides valuable source of information on the concentration and bioaccumulation of heavy metals in the environment and aquatic organisms. This paper determined the concentration of some trace metals in the moon fish Citharuscitharus obtained from Taylor Creek.

\section{Material and Method.}

Study Area

The study was carried out in Taylor Creek (Fig.1), North-east of Bayelsa State. Taylor Creek is a tributary of the River Nun. Major Communities along the creek include Agbia, Ogboloma, Ebiyai, Okolobiri, 


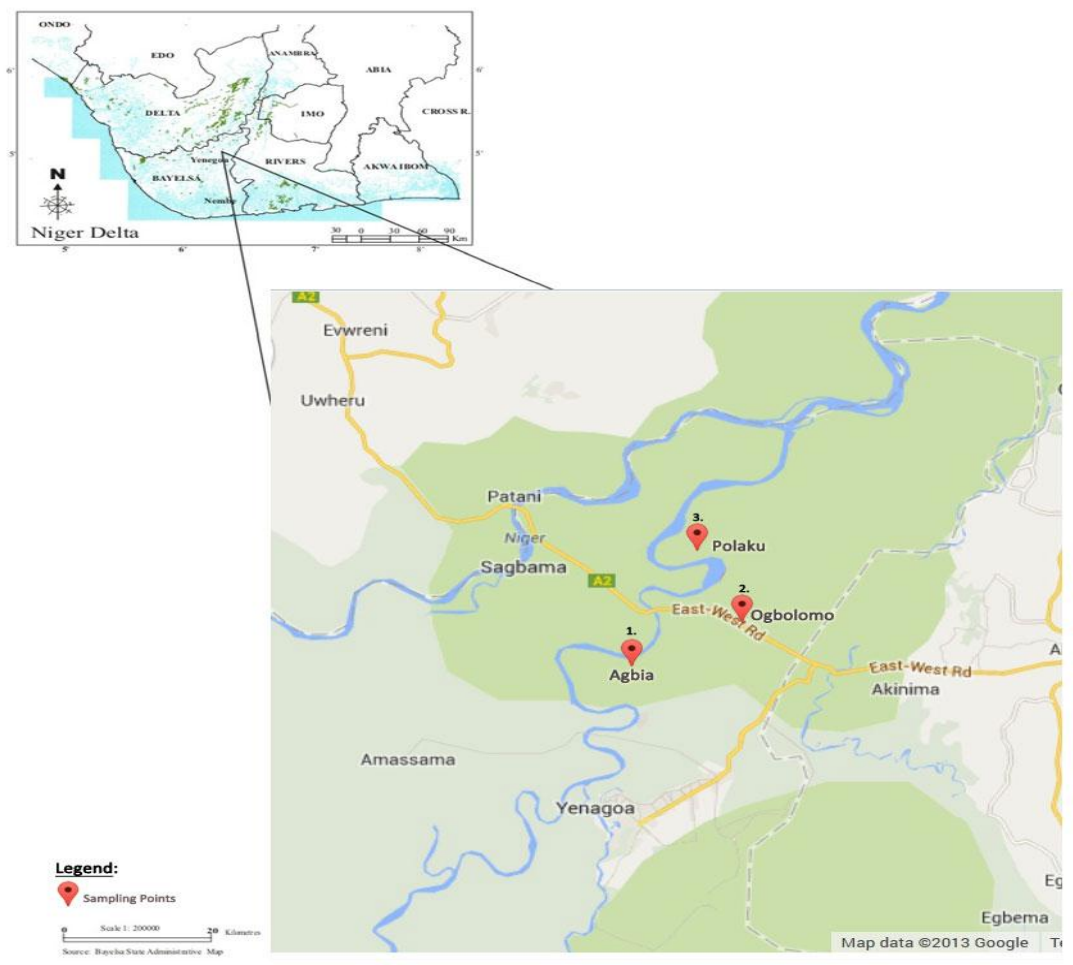

Fig.1 Map of Study Area.

Nedugo and Polaku arrangedin that order. The entire stretch from Agbia to Polakuis about 16km and lies between longitude $006^{0} 17^{1}$ to $006^{0} 21^{1} \mathrm{E}$ and Latitude $05^{0} 01^{1}$ to $05^{0} 05^{1} \mathrm{~N}$ respectively.

\section{Samples Collection and Analysis}

Three sampling stations were established along the creek course namely: Station 1, Ogboloma; Station 2, Okolobiri and station 3 Polaku. The sampling stations were chosen based on ecological settings and human activities in the area.

Fish samples were obtained from catches using drift net at the different stations. Nine fish sample were collected, three form each of the sampling stations. The length measurement were taken using a metre rule. They were sorted into three size groups namely small $(12-15 \mathrm{~cm})$, medium $(20-25 \mathrm{~cm})$ and large $(>39 \mathrm{~cm})$ and preserved in a deep freezer prior laboratory analysis.

\section{Determination of Trace Metals:}

Fish samples were allowed to thaw at room temperature and separated into whole samples and edible muscle, and oven dried at $105^{\circ} \mathrm{Cto}$ a constant weight and grounded to fine powder. About $2.5 \mathrm{~g}$ of the ground edible muscles were weighed and $10 \mathrm{ml}$ of metric/perchloric acid mixture (Ratio 2:1 by volume) was added to the samples and digested at $150^{\circ} \mathrm{C}$ until a clear solution was obtained. (Sreedevietal., 1992). 10ml of distilled water was added to digested samples to prevent formation of complex compounds and filtered. The filtrates were diluted with distilled water to $50 \mathrm{ml}$ and analyzed using plasma mass spectrophotometry (ICP-MS)model X series UK for evaluation of the three metals- $\operatorname{Lead}(\mathrm{Pb})$, Copper $(\mathrm{Cu})$ and $\operatorname{Cadmium}(\mathrm{Cd})$.

\section{Statistical Analysis.}

The data generated from the work were analyzed using one-way analysis of variance (ANOVA) for mean metal values comparison at 5\% level of significance. Differences among the means were separated using Turkey multiple comparisons.

\section{Result And Discussion:}

Trace Metal Concentration in Different Sizes of CitharinuscitharusObtained From Taylor Creek.

The sizes of fish (Citharinuscitharus) used in this study, were basically three. They are; large (41.92 \pm $0.96 \mathrm{~cm}, 39.14 \pm, 0.96 \mathrm{~cm}, 40.29 \pm, 0.96 \mathrm{~cm})$, medium $(20.62 \pm, 0.29 \mathrm{~cm}, 25.38 \pm 0.29 \mathrm{~cm}, 21.91 \pm 0.29 \mathrm{~cm})$ and small sizes $(15 \pm 0.09 \mathrm{~cm}, 12.19 \pm 0.09 \mathrm{~cm}, 12.10 \pm 0.09 \mathrm{~cm})$. The trace metals levels, were observed to be more concentrated in the larger sizes of fish as shown in Tables 1,2 and 3 respectively. In station 1 for instance, large fish recorded highest metals levels in all cases; $\mathrm{Cu}(0.671 \pm 0.07 \mu \mathrm{g} / \mathrm{g}), \mathrm{Pb}(0.144 \pm 0.005 \mu \mathrm{g} / \mathrm{g})$ and $\mathrm{Cd}(0.107 \pm$ 
$0.002 \mu \mathrm{g} / \mathrm{g})$.Station 2 recorded highest and least metal values in large and small fish in $\mathrm{Pb}(0.084 \pm 0.007$ and $0.029 \pm 0.004) \mu \mathrm{g} / \mathrm{g}, \mathrm{Cd}(0.096 \pm 0.004$ and $0.0025 \pm 0.001) \mu \mathrm{g} / \mathrm{g}$. However for $\mathrm{Cu}$, the highest and least values $(0.521 \pm 0.009$ and $0.041 \pm 0.007) \mu \mathrm{g} / \mathrm{g}$ were recorded in large and medium size fish respectively.

Table 1: Mean Concentration of Trace Metals $(\mu \mathrm{g} / \mathrm{g})$ in the Tissues of Citharinuscitharusin Station 1

\begin{tabular}{llll}
\hline Sizes of Citharinuscitharus & $(\mathrm{Cu})$ & $(\mathrm{Pd})$ & $(\mathrm{Cd})$ \\
\hline Larger sizes & $0.671 \pm 0.007$ & $0.144 \pm 0.005$ & $0.107 \pm 0.002$ \\
Medium sizes & $0.481 \pm 0.006$ & $0.110 \pm 0.000$ & $0.102 \pm 0.000$ \\
Small sizes & $0.271 \pm 0.009$ & $0.101 \pm 0.007$ & $0.029 \pm 0.005$ \\
\hline
\end{tabular}

Table 2: Mean Concentration of Trace Metals $(\mu \mathrm{g} / \mathrm{g})$ in the Tissues of Citharinuscitharusin Station 2

\begin{tabular}{llll}
\hline Sizes of Citharinuscitharus & $(\mathrm{Cu})$ & $(\mathrm{Pd})$ & $(\mathrm{Cd})$ \\
\hline Larger sizes & $0.521 \pm 0.009$ & $0.084 \pm 0.007$ & $0.096 \pm 0.004$ \\
Medium sizes & $0.041 \pm 0.007$ & $0.052 \pm 0.001$ & $0.032 \pm 0.004$ \\
Small sizes & $0.157 \pm 0.008$ & $0.029 \pm 0.004$ & $0.025 \pm 0.001$ \\
\hline
\end{tabular}

Table 3: Mean Concentration of Trace Metals $(\mu \mathrm{g} / \mathrm{g})$ in the Tissues of Citharinuscitharusin Station 3

\begin{tabular}{llll}
\hline Sizes of Citharinuscitharus & $(\mathrm{Cu})$ & $(\mathrm{Pd})$ & $(\mathrm{Cd})$ \\
\hline Larger sizes & $0.117 \pm 0.016$ & $0.103 \pm 0.008$ & $0.065 \pm 0.006$ \\
Medium sizes & $0.115 \pm 0.008$ & $0.101 \pm 0.000$ & $0.035 \pm 0.005$ \\
Small sizes & $0.112 \pm 0.006$ & $0.091 \pm 0.000$ & $0.015 \pm 0.001$ \\
\hline
\end{tabular}

Trace metals values obtained in Citharinuscitharusat the different stations in Taylor Creek.

The values of trace metals under consideration $(\mathrm{Cu}, \mathrm{Pd}$ and $\mathrm{Cd})$ detected in Citharinuscitharusis shown in Table 4. Findings of the study indicated that thetrace metals were more concentrated in station $1, \mathrm{Cu}(0.474$ \pm . $0.11 \mu \mathrm{g} / \mathrm{g} ; \mathrm{Cd}(0.118 \pm 0.0001 \mu \mathrm{g} / \mathrm{g})$. Next in qualigram was station $2, \mathrm{Cu}(0.115 \pm 0.013 \mu \mathrm{g} / \mathrm{g}) \mathrm{Pd}(0.055 \pm$ $0.159 \mu \mathrm{g} / \mathrm{g}) \mathrm{Cd}(0.098 \pm 0.004 \mu \mathrm{g} / \mathrm{g}) \mathrm{m}$, while the least in each case were recorded in station 3 (Table 4). Although the least value of $\mathrm{Pd}$ was obtained in station 2.

Table 4: Mean Concentration of Trace Metals ( $\mu \mathrm{g} / \mathrm{g})$ inCitharinuscitharus at the different Stations in Taylor Creek.

\begin{tabular}{llll}
\hline S/N & Name of Station & Elemental Elements & Mean \pm Standard Error \\
\hline 1 & Ogboloma Station 1 & Copper $(\mathrm{Cu})$ & $0.474 \pm 0.116$ \\
& & Lead $(\mathrm{Pd})$ & $0.033 \pm 0.105$ \\
& & Cadmium $(\mathrm{Cd})$ & $0.115 \pm 0.001$ \\
2 & Okolobiri Station 2 & Copper $(\mathrm{Cu})$ & $0.118 \pm 0.013$ \\
& & Lead $(\mathrm{Pd})$ & $0.055 \pm 0.159$ \\
& & Cadmium $(\mathrm{Cd})$ & $0.098 \pm 0.004$ \\
3 & Polaku Station 3 & Copper $(\mathrm{Cu})$ & $0.079 \pm 0.025$ \\
& & Lead $(\mathrm{Pd})$ & $0.053 \pm 0.022$ \\
& & Cadmium $(\mathrm{Cd})$ & $0.038 \underline{ \pm 0} 0.015$ \\
\hline
\end{tabular}

\section{Discussion:}

Trace metals are non-biodegrableand are considered as major environmental pollutants causing cytotoxic, mutagenic and carcinogenic effects in animals (More et al.,2003). The concentration of metals in the tissues of fish in the aquatic system vary considerably in different studies (Chattopardhayet al., 2002) possibly due to difference in metal concentrations in environment from which fish were sampled (Paragianniset al., 2004). The result of this study revealed that the large sizes of fish (Citharinus citharus) accumulated more metals than those of the other sizes.

This result corroborates the findings of Atololaye and Aremu (2007) inMeganiconfluence of Nasarawa State Nigeria. Similarly, Dura et al.,(2002) and Poetz et al.,(2007) reported highest levels of copper, zinc, lead, cadmium and iron in the large sizes of Sparus aurata and Mugilcephalus respectively. The higher values of trace elements in larger fish sizes in relation to smaller ones of the same species may be attributed to the strong affinity of metallothionine protein with these elements. This is usually more pronounced in bigger fishes. AllenGrill and Martynov (1995), postulated that low level of copper and zinc in smaller size of fish, may be due to low levels of binding proteins in the body of the fish. On the other hand, fairly high values of trace metals detected in fish at different stations of this study could be as a result of human activities occasioned by rapid urbanization. The high level of $\mathrm{Cd}$ element detected at the site may be attributed to ongoing construction work by Daewoo company at Ogboloma during the study. Thefish (Citharinuscitharus) being a detrivore, may have 
accumulated these metals from the metal contaminated bed along with fish food. This compares favourably with the findings of Howard, et al., (2009).

\section{Summary, Conclusion And Recommendation:}

The result of this study, supplied valuable information on the metal contents in (Citharinus citharus) from the different sampling stations in Taylor Creek. Larger sizes of this species exhibited tendency to accumulate $\mathrm{Cu}$, $\mathrm{Pd}$, and $\mathrm{Cd}$ than lower size groups. The study also showed that fish have high potential to concentrate trace metals, and the observed concentrations exceeded the certified permissive value to protect health of fish. The value recorded for $\mathrm{Cu}$ in larger fish $(0.671 \mu \mathrm{g} / \mathrm{g})$ at station 1 was slightly above $(0.600 \mu \mathrm{g} / \mathrm{g})$ maximum admissible limit to protect fish health. There is need to restrict and control discriminate dumping/discharge of domestic waste and effluent from homes/industries which are major sources of trace metals into the water bodies.

It was observed that the moon fish (Citharinus citharus) from Taylor Creek is burdened with metals and therefore must be monitored periodically to avoid excessive intake of trace metals by fish and humans. Conclusively it is expedient to postulate that, in order to evaluate the ecological condition of fish in the aquatic system, different sizes of same species should be monitored on regular basis. This is to determine contamination levels of fish as well as controlled entry of pollutants into the aquatic system for a healthier society.

\section{References:}

[1] Adams T., Afchison G.T. Utter, R.J (1980). The Impact of an industrialcontaminated lake on heavy metals levels in its Effluent stream. Hydrobiogia 69(1-2): 1870193.

[2] Allen-Grill, S.M and Martynov, V.G (1995).Heavy Metals Burden in nine species of fresh water and Anatropous fish from the Pechora river, Northern Russia science total environment. 160-161:653-659.

[3] Boia, M.N., F.A. Carvalho-Costa; F.C Soder; G.M.T and Amendoeira M.R.R. (2011).Seroprevalence of Toxoplasma gondi infection on rat. 50:17-20 Cross Ref, Pubmed

[4] Burton, J.G.A and Scot, K.J. (1992). Sediment Toxicity Evaluation, their Niche in

[5] Ecological Assessment. Environ. 34,279-288.

[6] Chattopadhay, B.A;Chatterjee and S.K. Mukopadhay(2002). Bioaccumulation of metals in the east calculta Wetland Ecosystem. Aquat ecosystem. Health Management. 5(2): 191-203.

[7] Dural, M., M.Z.L. Goksu and A.A. Ozak (2007) Investigation of Heavy Metal levels in Economically important Fish Species captured from the Tuzia Lagoon. Food chemical. 102: 415-421.

[8] Howard, Sadeghi., Stephen and Stoker, H. (2009) environmental chemistry: Air and water pollution. Glenview: Scott. Foreman and company.

[9] Ikogha D.P. (2012). Trace metal concentration in the muscle tissues of moon fish (CitharinusCitharus) From Taylor creek in Bayelsa State-Nigeria. BSc. Project-Niger Delta University, Wilberforce IslandBayelsa State Nigeria. 20-28.

[10] Much, A., Osibanjo, O and Ajayi, S.O. (2003). Pollution studies on Nigeria Rivers: The Onset of lead pollution of surface water in Ibadan Environ Int. (81-84).

[11] Papagiannis D.A(2004). Chemistry and Biochemistry of Trace metals in Biological system. In: LeepNw, Editor. Effect of Heavy metal Pollution on Plants: Effects of Trace Metals on Plant Function, Vol 1 London and newJersey: Applied Sci. Publ., 1981. P 154.

[12] Ploetz D.M. B.E. Fitts and T.M. Rice (2007) Differential accummulation of Heavy Metals Fish (King Mackerel 1, Scomberomorus Cavalla, Cuvier) from the Northern Gulf of Mexico, USA. Bull Environ. Toxico. 1., 78; $134-137$.

[13] Rasheed M.N. (2001). Monitoring of Environmental heavy Metals in Fish from Nasser lake.Environmental International, 27,27-33.

[14] Sreederi;P., Suresh, A., SiramakrismaB., Radhaknshala K, (1992).Bioaccumlation of Ni in capio and the fresh water Mussel LemelandensMarginal under Lethal and sub lethalNickelstressChemosphere24(1): 29-36. 